\title{
G-T haplotype established by rs3785889-rs16941382 in GOSR2 gene is associated with coronary artery disease in Chinese Han population
}

\author{
Shuo Pan ${ }^{1, *}$, Gong-Chang Guan ${ }^{1, *}$, Ying Lv ${ }^{1, *}$, Zhong-Wei Liu ${ }^{1}$, Fu-Qiang Liu ${ }^{1}$, Yong \\ Zhang $^{1}$, Shun-Ming Zhu ${ }^{1}$, Rong-Huai Zhang ${ }^{1}$, Na Zhao ${ }^{1}$, Shuang Shi', Tomohiro \\ Nakayama ${ }^{2}$ and Jun-Kui Wang ${ }^{1}$ \\ ${ }^{1}$ First Department of Cardiology, People's Hospital of Shaanxi Province, Xi'an, People's Republic of China \\ ${ }^{2}$ Division of Laboratory Medicine, Department of Pathology and Microbiology, Nihon University School of Medicine, Tokyo, \\ Japan \\ * These authors have contributed equally to this work \\ Correspondence to: Jun-Kui Wang, email: wjk_sx@163.com
}

Keywords: coronary artery disease, GOSR2, single nucleotide polymorphism, haplotype, genetic

Received: March 06, $2017 \quad$ Accepted: June 18, $2017 \quad$ Published: July 17, 2017

Copyright: Pan et al. This is an open-access article distributed under the terms of the Creative Commons Attribution License 3.0 (CC BY 3.0), which permits unrestricted use, distribution, and reproduction in any medium, provided the original author and source are credited.

\section{ABSTRACT}

Objectives: The aim of the present study is to assess the association between the human GOSR2 gene and coronary artery disease using a haplotype-based casecontrol study in Chinese Han population.

Methods: A total of $\mathbf{2 8 3}$ coronary artery disease patients and $\mathbf{2 8 0}$ controls were genotyped for the human GOSR2 gene (rs197932, rs3785889, rs197922, rs17608766, and rs16941382). Data were analyzed for three separate groups: the total subjects, men, and women.

Results: For the total subjects, the frequency of the G-T haplotype established by rs3785889-rs16941382 was significantly higher in the coronary artery disease patients as compared to the control subjects $(P=0.009)$. Multiple logistic regression analysis also confirmed that the subjects with G-T haplotype established by rs3785889-rs16941382 (homozygote) were found having significantly higher chance suffering from coronary artery disease than the ones without this haplotype (OR=1.887, $P=0.007$ ).

Conclusions: The G-T haplotype established by rs3785889-rs16941382 may be a risk genetic marker for coronary artery disease patients in Chinese Han population.

\section{INTRODUCTION}

Coronary artery disease $(\mathrm{CAD})$ is a widely spread disease worldwide, its pathogenesis includes both environmental and genetic factors [1], many hereditary features were reported to show significant connections with CAD in previous investigations [2-3].

Golgi Snap receptor complex member 2 (GOSR2) is one of the Golgi-associated soluble N-ethylmaleimidesensitive factor attachment receptor (SNARE) proteins, its main function included the transportation via Golgi complex in different cells [4]. The function also includes interaction with target-localized SNAREs (t-SNAREs), with which the insulin, leptin, angiotensinogen and other macromolecules would go through Golgi compartments [5-7].

One study based on American population reported that the A allele in rs197922 of GOSR2 gene was a risk factor for myocardial infarction (OR=1.17, $P=0.032$ ) [8]. Pan et al [9] did not find A allele was an significant risk or protective factor for MI, however, base on Japanese population, the T-G-G haplotype of rs197932-rs3785889rs197922 in GOSR2 was found to show beneficial effects against the occurrences of myocardial infarction. 
Table 1: Characteristics of study participants

\begin{tabular}{|c|c|c|c|c|c|c|c|c|c|}
\hline & \multicolumn{3}{|c|}{ Total } & \multicolumn{3}{|c|}{ Men } & \multicolumn{3}{|c|}{ Women } \\
\hline & CAD patients & $\begin{array}{l}\text { Control } \\
\text { subjects }\end{array}$ & $P$ value & $\begin{array}{c}\text { CAD } \\
\text { patients }\end{array}$ & $\begin{array}{l}\text { Control } \\
\text { subjects }\end{array}$ & $P$ value & $\begin{array}{c}\text { CAD } \\
\text { patients }\end{array}$ & $\begin{array}{l}\text { Control } \\
\text { subjects }\end{array}$ & $P$ value \\
\hline Number of subjects & 283 & 280 & & 134 & 151 & & 149 & 129 & \\
\hline Age (years) & $56.56 \pm 11.28$ & $56.60 \pm 12.52$ & 0.907 & $55.51 \pm 8.75$ & $55.60 \pm 12.41$ & 0.885 & $58.48 \pm 14.80$ & $58.41 \pm 12.55$ & 0.834 \\
\hline $\operatorname{BMI}\left(\mathrm{kg} / \mathrm{m}^{2}\right)$ & $25.45 \pm 3.08$ & $25.89 \pm 3.17$ & 0.119 & $23.12 \pm 1.76$ & $26.23 \pm 2.91$ & $<0.001 *$ & $27.90 \pm 2.12$ & $25.49 \pm 3.42$ & $<0.001 *$ \\
\hline Pulse (beats/min) & $72.90 \pm 11.30$ & $73.34 \pm 10.11$ & 0.632 & $73.08 \pm 12.27$ & $74.55 \pm 10.92$ & 0.289 & $72.74 \pm 10.39$ & $71.91 \pm 9.89$ & 0.480 \\
\hline $\begin{array}{l}\text { Total cholesterol } \\
(\mathrm{mmol} / \mathrm{L})\end{array}$ & $4.28 \pm 1.04$ & $4.41 \pm 1.03$ & 0.132 & $4.25 \pm 1.12$ & $4.31 \pm 1.03$ & 0.637 & $4.30 \pm 0.97$ & $4.52 \pm 1.02$ & 0.067 \\
\hline Triglycerides (mmol/L) & $2.04 \pm 1.78$ & $1.94 \pm 1.33$ & 0.430 & $1.93 \pm 2.05$ & $2.17 \pm 1.57$ & 0.285 & $2.14 \pm 1.51$ & $1.67 \pm 0.92$ & $0.003 *$ \\
\hline $\mathrm{LDL}(\mathrm{mmol} / \mathrm{L})$ & $2.56 \pm 0.93$ & $2.56 \pm 8.77$ & 0.972 & $2.47 \pm 0.94$ & $2.52 \pm 0.85$ & 0.642 & $2.65 \pm 0.92$ & $2.61 \pm 0.91$ & 0.719 \\
\hline HDL (mmol/L) & $1.16 \pm 0.34$ & $1.15 \pm 0.39$ & 0.749 & $1.25 \pm 0.40$ & $1.08 \pm 0.41$ & $0.001^{*}$ & $1.08 \pm 0.24$ & $1.23 \pm 0.35$ & $<0.001^{*}$ \\
\hline $\begin{array}{l}\text { Fasting glucose } \\
(\mathrm{mmol} / \mathrm{L})\end{array}$ & $6.21 \pm 2.39$ & $5.67 \pm 1.83$ & $0.003 *$ & $6.36 \pm 2.47$ & $5.75 \pm 2.04$ & $0.026^{*}$ & $6.08 \pm 2.31$ & $5.57 \pm 1.56$ & $0.033 *$ \\
\hline Creatinine $(\mathrm{mmol} / \mathrm{L})$ & $74.88 \pm 24.07$ & $71.65 \pm 17.60$ & 0.058 & $74.61 \pm 21.34$ & $76.41 \pm 17.17$ & 0.092 & $75.13 \pm 22.77$ & $66.15 \pm 16.51$ & $<0.001^{*}$ \\
\hline Hypertension (\%) & $183(64.66 \%)$ & $168(60.00 \%)$ & 0.259 & $89(66.42 \%)$ & $95(62.91 \%)$ & 0.620 & $94(63.09 \%)$ & $73(56.59 \%)$ & 0.326 \\
\hline DM (\%) & $107(37.81 \%)$ & $50(17.86 \%)$ & $<0.001^{*}$ & $42(31.34 \%)$ & $33(21.85 \%)$ & 0.080 & $65(43.62 \%)$ & $17(13.18 \%)$ & $<0.001^{*}$ \\
\hline
\end{tabular}

Continuous variables are expressed as mean \pm S.D. Categorical variables are expressed as percentages. CAD, coronary artery disease; BMI, body mass index; LDL, low-density lipoprotein; HDL, high-density lipoprotein; DM, diabetes mellitus. The P value of the continuous variables was calculated by the Mann-Whitney U-test. The P value of the categorical variables was calculated by Fisher's exact test. ${ }^{*} P<0.05$.

However, in Chinese Han population, there is no such study to evaluate the relationship between GOSR2 gene and CAD. Therefore, the present paper is intended to discover the possible connection between the human GOSR2 gene and CAD in Chinese Han population.

\section{RESULTS}

Table 1 presented the dimorphic and laboratory data in patients with or without CAD. For total subjects, fasting glucose and incidence of diabetes in CAD patients were higher than those in the control subjects significantly $(P<0.05)$. For men, body mass index, high density lipoprotein (HDL) and fasting glucose in CAD patients were different with those in control subjects significantly $(P<0.05)$. In women, body mass index, triglycerides, HDL, fasting glucose, creatinine and incidence of diabetes in CAD patients were different with those in control subjects significantly $(P<0.05)$.

Table 2 presents the genotyping and allele frequency as well as the frequencies in dominant and recessive models between the CAD patients and control subjects for each SNP. For each single nucleotide polymorphism (SNP), the frequency of genotype was consistent with Hardy-Weinberg equilibrium (data not shown). The genotype distributions showed no significant difference for the all 5 SNPs in GOSR2. For total, men and women subjects, the distribution frequency showed no significant difference in the allele distribution as well as the dominant and recessive model distribution.
The linkage disequilibrium data of the selected 4 SNPs are presented in Table 3. All the 5 SNPs were confirmed to be placed in the same haplotype block according to the $\left|\mathrm{D}^{\prime}\right|$ values. As the frequency of $\mathrm{C}$ allele in SNP4 was too low for the haplotype construction. Meanwhile, since $r^{2}$ for SNP3-SNP5 was 0.672, which was above 0.5 in the participants, indicating that SNP3 and SNP5 may not be applied for constructing haplotypes at the same time. Considering that the genotype distribution difference in SNP5 was more significant than that in SNP3, we chose SNP1, SNP2, and SNP5 to construct the haplotype.

Table 4 presented thehaplotype-based analysis via the establishment of haplotype using SNP1-SNP2-SNP5, SNP1-SNP2, SNP1-SNP5, SNP2-SNP5. In total subjects, the overall SNP2-SNP5 haplotype distribution differed significantly between the CAD patients and the controls $(P=0.031)$. In total subjects, the G-T haplotype frequency constructed via SNP2-SNP5 in the CAD patients was higher than that in the controls $(0.468$ vs $0.389, P=$ 0.009). Meanwhile, in men, the G-T haplotype frequency constructed via SNP2-SNP5 in CAD patients was also higher than that in control subjects $(0.459$ vs $0.360, P=$ 0.021 ). As in women, the same distribution patterns were not noticed.

The software SNPAlyze version 8.2 was applied to construct the diplotypes for every single patient. The H13 (homozygote) was taken into the logistic regression analysis as one potential risk factor, other confounding such as diabetes mellitus, hypertension, low density 
Table 2: Genotyping and allele distributions in control subjects and patients with CAD

\begin{tabular}{|c|c|c|c|c|c|c|c|c|c|}
\hline \multirow[b]{2}{*}{ Variants } & \multicolumn{3}{|c|}{ Total } & \multicolumn{3}{|c|}{ Men } & \multicolumn{3}{|c|}{ Women } \\
\hline & $\begin{array}{c}\text { CAD } \\
\text { patients }\end{array}$ & $\begin{array}{l}\text { Control } \\
\text { subjects }\end{array}$ & $\begin{array}{c}P \\
\text { value }\end{array}$ & CAD patients & $\begin{array}{l}\text { Control } \\
\text { subjects }\end{array}$ & $P$ value & CAD patients & $\begin{array}{l}\text { Control } \\
\text { subjects }\end{array}$ & $P$ value \\
\hline \multicolumn{10}{|c|}{ rs197932(SNP1) } \\
\hline \multicolumn{10}{|l|}{ Genotyping } \\
\hline $\mathrm{CC}$ & $27(9.5 \%)$ & $17(6.1 \%)$ & & $14(10.4 \%)$ & $6(4.0 \%)$ & & $13(8.7 \%)$ & $11(8.5 \%)$ & \\
\hline $\mathrm{CT}$ & $112(39.6 \%)$ & $115(41.1 \%)$ & & $51(38.1 \%)$ & $63(41.7 \%)$ & & $61(40.9 \%)$ & $52(40.3 \%)$ & \\
\hline $\mathrm{TT}$ & $144(50.9 \%)$ & $148(52.9 \%)$ & 0.324 & $69(51.5)$ & $82(54.3 \%)$ & 0.109 & $75(50.3 \%)$ & $66(51.2 \%)$ & 1.000 \\
\hline \multicolumn{10}{|c|}{ Dominant model } \\
\hline $\mathrm{TT}$ & $144(50.9 \%)$ & $148(52.9 \%)$ & & $69(51.5 \%)$ & $82(54.3 \%)$ & & $75(50.3 \%)$ & $66(51.2 \%)$ & \\
\hline $\mathrm{CC}+\mathrm{CT}$ & $139(49.1 \%)$ & $132(47.1 \%)$ & 0.673 & $65(48.5 \%)$ & $69(45.7 \%)$ & 0.721 & $74(49.7 \%)$ & $63(48.8 \%)$ & 0.905 \\
\hline \multicolumn{10}{|c|}{ Recessive model } \\
\hline $\mathrm{CC}$ & $27(9.5 \%)$ & $17(6.1 \%)$ & & $14(10.4 \%)$ & $6(4.0 \%)$ & & $13(8.7 \%)$ & $11(8.5 \%)$ & \\
\hline $\mathrm{TT}+\mathrm{CT}$ & $256(90.5 \%)$ & $263(93.9 \%)$ & 0.157 & $120(89.6 \%)$ & $145(96.0 \%)$ & 0.068 & $136(91.3 \%)$ & $118(91.5 \%)$ & 1.000 \\
\hline \multicolumn{10}{|l|}{ Allele } \\
\hline $\mathrm{C}$ & $166(29.3 \%)$ & $149(26.6 \%)$ & & $79(29.5 \%)$ & $75(24.8 \%)$ & & $87(29.2 \%)$ & $74(28.7 \%)$ & \\
\hline $\mathrm{T}$ & $400(70.7 \%)$ & $411(73.4 \%)$ & 0.320 & $189(70.5 \%)$ & $227(75.2 \%)$ & 0.221 & $211(70.8 \%)$ & $184(71.3 \%)$ & 0.925 \\
\hline \multicolumn{10}{|c|}{ rs3785889(SNP2) } \\
\hline \multicolumn{10}{|l|}{ Genotyping } \\
\hline AA & $27(9.5 \%)$ & $26(9.3 \%)$ & & $11(8.2 \%)$ & $15(9.9 \%)$ & & $16(10.7 \%)$ & $11(8.5 \%)$ & \\
\hline $\mathrm{AG}$ & $105(37.1 \%)$ & $127(45.4 \%)$ & & $50(37.3 \%)$ & $68(45.0 \%)$ & & $55(36.9 \%)$ & $59(45.7 \%)$ & \\
\hline GG & $151(53.4 \%)$ & $127(45.4 \%)$ & 0.124 & $73(54.5 \%)$ & $68(45.0 \%)$ & 0.286 & $78(52.3 \%)$ & $59(45.7 \%)$ & 0.320 \\
\hline \multicolumn{10}{|c|}{ Dominant model } \\
\hline GG & $151(53.4 \%)$ & $127(45.4 \%)$ & & $73(54.5 \%)$ & $68(45.0 \%)$ & & $78(52.3 \%)$ & $59(45.7 \%)$ & \\
\hline $\mathrm{AA}+\mathrm{AG}$ & $132(46.6 \%)$ & $153(54.6 \%)$ & 0.064 & $61(45.5 \%)$ & $83(55.0 \%)$ & 0.124 & $71(47.7 \%)$ & $70(54.3 \%)$ & 0.282 \\
\hline \multicolumn{10}{|c|}{ Recessive model } \\
\hline $\mathrm{AA}$ & $27(9.5 \%)$ & $26(9.3 \%)$ & & $11(8.2 \%)$ & $15(9.9 \%)$ & & $16(10.7 \%)$ & $11(8.5 \%)$ & \\
\hline $\mathrm{GG}+\mathrm{AG}$ & $256(90.5 \%)$ & $254(90.7 \%)$ & 1.000 & $123(91.8 \%)$ & $136(90.1 \%)$ & 0.683 & $133(89.3 \%)$ & $118(91.5 \%)$ & 0.551 \\
\hline \multicolumn{10}{|l|}{ Allele } \\
\hline A & $159(28.1 \%)$ & $179(32.0 \%)$ & & $72(26.9 \%)$ & $98(32.5 \%)$ & & $87(29.2 \%)$ & $81(31.4 \%)$ & \\
\hline G & $407(71.9 \%)$ & $381(68.0 \%)$ & 0.172 & $196(73.1 \%)$ & $204(67.5 \%)$ & 0.169 & $211(70.8 \%)$ & $177(68.6 \%)$ & 0.580 \\
\hline \multicolumn{10}{|c|}{ rs197922(SNP3) } \\
\hline \multicolumn{10}{|l|}{ Genotyping } \\
\hline AA & $43(15.2 \%)$ & $38(13.6 \%)$ & & $27(20.1 \%)$ & $24(15.9 \%)$ & & $16(10.7 \%)$ & $14(10.9 \%)$ & \\
\hline $\mathrm{AG}$ & $125(44.2 \%)$ & $139(49.6 \%)$ & & $57(42.5 \%)$ & $71(47.0 \%)$ & & $68(45.6 \%)$ & $68(52.7 \%)$ & \\
\hline GG & $115(40.6 \%)$ & $103(36.8 \%)$ & 0.436 & $50(37.3 \%)$ & $56(37.1 \%)$ & 0.590 & $65(43.6 \%)$ & $47(36.4 \%)$ & 0.437 \\
\hline \multicolumn{10}{|c|}{ Dominant model } \\
\hline $\mathrm{AG}$ & $125(44.2 \%)$ & $139(49.6 \%)$ & & $57(42.5 \%)$ & $71(47.0 \%)$ & & $68(45.6 \%)$ & $68(52.7 \%)$ & \\
\hline $\mathrm{AA}+\mathrm{GG}$ & $158(55.8 \%)$ & $141(50.4 \%)$ & 0.206 & $77(57.5 \%)$ & $80(53.0 \%)$ & 0.475 & $81(54.4 \%)$ & $61(47.3 \%)$ & 0.279 \\
\hline \multicolumn{10}{|c|}{ Recessive model } \\
\hline $\mathrm{AA}$ & $43(15.2 \%)$ & $38(13.6 \%)$ & & $27(20.1 \%)$ & $24(15.9 \%)$ & & $16(10.7 \%)$ & $14(10.9 \%)$ & \\
\hline $\mathrm{GG}+\mathrm{AG}$ & $240(84.8 \%)$ & $242(86.4 \%)$ & 0.632 & $107(79.9 \%)$ & $127(84.1 \%)$ & 0.358 & $133(89.3 \%)$ & $115(89.1 \%)$ & 1.000 \\
\hline
\end{tabular}

(Continued) 


\begin{tabular}{|c|c|c|c|c|c|c|c|c|c|}
\hline \multirow[b]{2}{*}{ Variants } & \multicolumn{3}{|c|}{ Total } & \multicolumn{3}{|c|}{ Men } & \multicolumn{3}{|c|}{ Women } \\
\hline & $\underset{\text { patients }}{\text { CAD }}$ & $\begin{array}{l}\text { Control } \\
\text { subjects }\end{array}$ & $\begin{array}{c}P \\
\text { value }\end{array}$ & CAD patients & $\begin{array}{l}\text { Control } \\
\text { subjects }\end{array}$ & $P$ value & CAD patients & $\begin{array}{l}\text { Control } \\
\text { subjects }\end{array}$ & $P$ value \\
\hline \multicolumn{10}{|l|}{ Allele } \\
\hline $\mathrm{A}$ & $211(37.3 \%)$ & $215(38.4 \%)$ & & $111(41.4 \%)$ & $119(39.4 \%)$ & & $100(33.6 \%)$ & $96(37.2 \%)$ & \\
\hline G & $355(62.7 \%)$ & $345(61.6 \%)$ & 0.713 & $157(58.6 \%)$ & $183(60.6 \%)$ & 0.669 & $198(66.4 \%)$ & $162(62.8 \%)$ & 0.375 \\
\hline \multicolumn{10}{|c|}{ rs17608766(SNP4) } \\
\hline \multicolumn{10}{|c|}{ Genotyping } \\
\hline $\mathrm{TT}$ & $281(99.3 \%)$ & $277(98.9 \%)$ & & $134(100 \%)$ & $149(98.7 \%)$ & & $147(98.7 \%)$ & $128(99.2 \%)$ & \\
\hline $\mathrm{CT}$ & $2(0.7 \%)$ & $3(1.1 \%)$ & & $0(0 \%)$ & $2(1.3 \%)$ & & $2(1.3 \%)$ & $1(0.8 \%)$ & \\
\hline $\mathrm{CC}$ & $0(0 \%)$ & $0(0 \%)$ & 0.685 & $0(0 \%)$ & $0(0 \%)$ & 0.500 & $0(0 \%)$ & $0(0 \%)$ & 1.000 \\
\hline \multicolumn{10}{|c|}{ Dominant model } \\
\hline $\mathrm{TT}$ & $281(99.3 \%)$ & $277(98.9 \%)$ & & $134(100 \%)$ & $149(98.7 \%)$ & & $147(98.7 \%)$ & $128(99.2 \%)$ & \\
\hline $\mathrm{CC}+\mathrm{CT}$ & $2(0.7 \%)$ & $3(1.1 \%)$ & 0.685 & $0(0 \%)$ & $2(1.3 \%)$ & 0.500 & $2(1.3 \%)$ & $1(0.8 \%)$ & 1.000 \\
\hline \multicolumn{10}{|c|}{ Recessive model } \\
\hline $\mathrm{CC}$ & $0(0 \%)$ & $0(0 \%)$ & & $0(0 \%)$ & $0(0 \%)$ & & $0(0 \%)$ & $0(0 \%)$ & \\
\hline $\mathrm{TT}+\mathrm{CT}$ & $283(100 \%)$ & $280(100 \%)$ & - & $134(100 \%)$ & $151(100 \%)$ & - & $149(100 \%)$ & $129(100 \%)$ & - \\
\hline \multicolumn{10}{|l|}{ Allele } \\
\hline $\mathrm{C}$ & $2(0.4 \%)$ & $3(0.5 \%)$ & & $0(0 \%)$ & $2(0.7 \%)$ & & $2(0.7 \%)$ & $1(0.4 \%)$ & \\
\hline $\mathrm{T}$ & $564(99.6 \%)$ & $557(99.5 \%)$ & 0.685 & $268(100 \%)$ & $300(99.3 \%)$ & 0.501 & $296(99.3 \%)$ & 257(99.6) & 1.000 \\
\hline \multicolumn{10}{|c|}{ rs16941382(SNP5) } \\
\hline \multicolumn{10}{|c|}{ Genotyping } \\
\hline $\mathrm{CC}$ & $21(7.4 \%)$ & $22(7.9 \%)$ & & $15(11.2 \%)$ & $17(11.3 \%)$ & & $6(4.0 \%)$ & $5(3.9 \%)$ & \\
\hline $\mathrm{CT}$ & $100(35.3 \%)$ & $121(43.2 \%)$ & & $43(32.1 \%)$ & $63(41.7 \%)$ & & $57(38.3 \%)$ & $58(45.0 \%)$ & \\
\hline $\mathrm{TT}$ & $162(57.2 \%)$ & $137(48.9 \%)$ & 0.132 & $76(56.7 \%)$ & $71(47.0 \%)$ & 0.218 & $86(57.7 \%)$ & $66(51.1 \%)$ & 0.564 \\
\hline \multicolumn{10}{|c|}{ Dominant model } \\
\hline TT & $162(57.2 \%)$ & $137(48.9 \%)$ & & $76(56.7 \%)$ & $71(47.0 \%)$ & & $86(57.7 \%)$ & $66(51.2 \%)$ & \\
\hline $\mathrm{CC}+\mathrm{CT}$ & $121(42.8 \%)$ & $143(51.1 \%)$ & 0.052 & $58(43.3 \%)$ & $80(53.0 \%)$ & 0.123 & $63(42.3 \%)$ & $63(48.8 \%)$ & 0.280 \\
\hline \multicolumn{10}{|c|}{ Recessive model } \\
\hline $\mathrm{CC}$ & $21(7.4 \%)$ & $22(7.9 \%)$ & & $15(11.2 \%)$ & $17(11.3 \%)$ & & $6(4.0 \%)$ & $5(3.9 \%)$ & \\
\hline $\mathrm{TT}+\mathrm{CT}$ & $262(92.6 \%)$ & $258(92.1 \%)$ & 0.875 & $119(88.8 \%)$ & $134(88.7 \%)$ & 1.000 & $143(96.0 \%)$ & $124(96.1 \%)$ & 1.000 \\
\hline \multicolumn{10}{|l|}{ Allele } \\
\hline $\mathrm{C}$ & $142(25.1 \%)$ & $165(29.5 \%)$ & & $73(27.2 \%)$ & $97(32.1 \%)$ & & $69(23.2 \%)$ & $68(26.4 \%)$ & \\
\hline $\mathrm{T}$ & $424(74.9 \%)$ & $395(70.5 \%)$ & 0.108 & $195(72.8 \%)$ & $205(67.9 \%)$ & 0.233 & $229(76.8 \%)$ & $190(73.6 \%)$ & 0.430 \\
\hline
\end{tabular}

$\mathrm{CAD}$, coronary artery disease; SNP, single-nucleotide polymorphism. ${ }^{*} P<0.05$.

lipoprotein (LDL), total cholesterol, triglycerides and creatinine were also taken into the logistic regression analysis as adjusting factors (Table 5). In total subjects, after the adjustments of hypertension, diabetes mellitus, low density lipoprotein (LDL), total cholesterol, triglycerides and creatinine, the subjects carrying the H13 diplotype (H13 homozygote) were shown to have increased probability of suffering from CAD than the those not carrying $\mathrm{H} 13$ diplotype (homozygote) ( $O R=1.887$, $P=0.007)$.

\section{DISCUSSION}

GOSR2 is a Golgi associated soluble factor attachment receptor (SNARE) protein, it built bridges to allow and promote membrane fusion via the endosomal and secretory pathways $[10,11]$. A twisted parallel bundle constructed by four amphipathic helices were contained in the SNARE complex $[12,13]$. Although the specific function of SNAREs, such as transport vesicles functions of docking and fusion, is still uncertain, some 


\begin{tabular}{cccccc}
\hline & & \multicolumn{3}{c}{$\mid$ D'| values } \\
\cline { 2 - 6 } & & SNP1 & SNP2 & SNP3 & SNP5 \\
\hline & SNP1 & & 0.248 & 0.836 & 0.958 \\
& SNP2 & 0.010 & & 1.000 & 0.968 \\
\cline { 2 - 6 } & SNP3 & 0.158 & 0.293 & & 0.967 \\
\hline
\end{tabular}

SNP, single nucleotide polymorphism. | $\mathrm{D}^{\prime} \mid$ values of $>0.5$ to assign SNP locations to one haplotype block. SNPs with an $r^{2}$ value $>0.5$ were selected as tagged. $\left|\mathrm{D}^{\prime}\right|$ above the diagonal and $\mathrm{r}^{2}$ below the diagonal. The shadowed portion indicates $\left|\mathrm{D}^{\prime}\right|$ $>0.5$ and $\mathrm{r}^{2}>0.5$.

studies confirmed that SNARE complexes played the key part in intracellular membrane fusion. The trafficking function of cardiovascular related macromolecules may be in the central stage for the association with multiple cardiovascular diseases such as CAD and hypertension $[9$, 14].

In one previous study based on the Japanese population, TT genotype is the only genotype in the rs 17608766 of GOSR2 [9]. In this study based on Chinese Han population, we found 2 subjects had the CT genotype in the $\mathrm{CAD}$ group and 3 subjects had the $\mathrm{CT}$ genotype in the control group in Chinese Han population. However, we did not notice the significant difference on $\mathrm{CT}$ and TT genotype distribution between the CHD patients and control subjects. One study based on American population reported that the A allele in rs197922 of GOSR2 gene was a risk factor for myocardial infarction (MI) $(\mathrm{OR}=1.17$, $P=0.032$ ) [8]. However, the study base on the Japanese population reported no significant difference for A allele in rs197922 between the control subjects and CAD patients. In this study based on Chinese Han population, the frequency of A allele in rs197922 of GOSR2 gene didn't show any significant difference between the control subjects and CAD patients $(P=0.713)$. Our results were consistent with the findings in Japanese population and were not consistent with the findings in American population. The differences may mainly be due to the races, since the Japanese population was more likely to be consistent in the origin with Chinese populations.

When the linkage disequilibrium among the SNPs appeared to be weak, the haplotypes analysis could be superior than individual SNPs analysis since it is consist with the human hereditary features [15]. In the previously described study based on Japanese population, after constructing all the possible haplotypes, they discovered that the frequency distribution of T-G-G haplotype, which was constructed with rs197932-rs3785889-rs197922, was lower in the myocardial infarction men when compared with that in the control men $(P=0.040)$. After adjusting the confounding factors, they found that the T-G-G haplotype including homozygous and heterozygous diplotypes may have protective effects on myocardial infarction in Japanese men ( $\mathrm{OR}=0.455, P=0.041)$ [9]. In this present study, we did not use the rs197932-rs3785889-rs197922 to establish the halotype since the genotype distribution difference in rs 16941382 was more significant than that in rs197922 in Chinese population. Therefore, we constructed the haplotype using rs 197932-rs3785889-rs16941382 and found a risk haplotype G-T of SNP2-SNP5 in total and male population. With the logistic regression analysis, the haplotype (G-T) is targeted as an novel risk factor for CAD in Chinese Han population ( $O R=1.887, P=0.007)$.

The mechanism that GOSR2 is associated with CAD is still not clear. Based on limited data, we supposed that three possible mechanisms may be involved in the association between the GOSR2 and CAD. First, the genome-wide association study (GWAS) showed that rs17608766 in GOSR2 had age-dependent effects on BP [16]. The association with blood pressure may accelerate the arteriosclerosis which would consequently make the some haplotypes in GOSR2 gene the risk factor of CAD. Second, Ghanbari M et al [17] identified that GOSR2 was one of the miR-4513 target genes, which may show multiple effects on lipid and glucose metabolism, blood pressure regulation as well as atherosclerosis. Then the association between GOSR 2 and coronary artery disease may be established via miRNA-4513 pathway. Third, GOSR2 has the function of coding for vesicular-SNARE (v-SNAREs), which was perceived as transporter of vesicles into the Golgi complex [18]. v-SNAREs would have influence on target-localized SNAREs (t-SNAREs), allowing the macromolecule substances to move directly across Golgi membrane $[19,20]$. Due to its trafficking function, the GOSR2 gene could be associated with the cardiovascular diseases which are highly associated with macromolecules such as insulin, leptin, and angiotensinogen.

Our study has several strengths. First, all case and control subjects underwent the coronary angiography, which is the golden standard for the diagnosis of CAD with the combination of clinical or electrocardiogram results. Second, the control subjects may have other 
Table 4: Haplotype analysis in patients with CAD and control subjects

\begin{tabular}{|c|c|c|c|c|c|c|c|c|c|c|c|c|c|c|c|}
\hline \multirow[b]{2}{*}{ Haplotype } & \multirow[b]{2}{*}{ SNP1 } & \multirow[b]{2}{*}{ SNP2 } & \multirow[b]{2}{*}{ SNP5 } & \multicolumn{3}{|c|}{ Overall $P$ value } & \multicolumn{3}{|c|}{ Frequency in total } & \multicolumn{3}{|c|}{ Frequency in men } & \multicolumn{3}{|c|}{ Frequency in women } \\
\hline & & & & Total & Men & Women & $\begin{array}{c}\text { CAD } \\
\text { patients }\end{array}$ & $\begin{array}{l}\text { Control } \\
\text { subjects }\end{array}$ & $\begin{array}{c}P \\
\text { value }\end{array}$ & $\begin{array}{c}\text { CAD } \\
\text { patients }\end{array}$ & $\begin{array}{l}\text { Control } \\
\text { subjects }\end{array}$ & $\begin{array}{c}P \\
\text { value }\end{array}$ & $\begin{array}{c}\text { CAD } \\
\text { patients }\end{array}$ & $\begin{array}{l}\text { Control } \\
\text { subjects }\end{array}$ & $\begin{array}{c}P \\
\text { value }\end{array}$ \\
\hline & & & & 0.149 & 0.278 & 0.445 & & & & & & & & & \\
\hline H1 & $\mathrm{T}$ & G & $\mathrm{C}$ & & & & 0.248 & 0.291 & 0.092 & 0.272 & 0.315 & 0.273 & 0.226 & 0.264 & 0.265 \\
\hline $\mathrm{H} 2$ & $\mathrm{~T}$ & A & $\mathrm{T}$ & & & & 0.229 & 0.251 & 0.435 & 0.207 & 0.261 & 0.138 & 0.248 & 0.238 & 0.804 \\
\hline $\mathrm{H} 3$ & $\mathrm{C}$ & G & $\mathrm{T}$ & & & & 0.239 & 0.198 & 0.126 & 0.233 & 0.188 & 0.243 & 0.245 & 0.211 & 0.354 \\
\hline $\mathrm{H} 4$ & $\mathrm{~T}$ & G & $\mathrm{T}$ & & & & 0.231 & 0.192 & 0.147 & 0.226 & 0.175 & 0.146 & 0.235 & 0.212 & 0.552 \\
\hline \multirow[t]{2}{*}{ H5 } & $\mathrm{C}$ & A & $\mathrm{T}$ & & & & 0.053 & 0.068 & 0.342 & 0.062 & 0.061 & 0.962 & 0.046 & 0.076 & 0.153 \\
\hline & & & & 0.425 & 0.599 & 0.589 & & & & & & & & & \\
\hline H6 & $\mathrm{T}$ & $\mathrm{G}$ & & & & & 0.476 & 0.478 & 0.930 & 0.490 & 0.481 & 0.864 & 0.463 & 0.474 & 0.798 \\
\hline $\mathrm{H} 7$ & $\mathrm{~T}$ & A & & & & & 0.231 & 0.256 & 0.416 & 0.215 & 0.271 & 0.195 & 0.245 & 0.239 & 0.897 \\
\hline $\mathrm{H} 8$ & $\mathrm{C}$ & G & & & & & 0.244 & 0.202 & 0.137 & 0.241 & 0.195 & 0.301 & 0.245 & 0.212 & 0.382 \\
\hline \multirow[t]{2}{*}{ H9 } & $\mathrm{C}$ & A & & & & & 0.050 & 0.064 & 0.447 & 0.054 & 0.054 & 0.989 & 0.047 & 0.075 & 0.288 \\
\hline & & & & 0.238 & 0.351 & 0.557 & & & & & & & & & \\
\hline H10 & $\mathrm{T}$ & & $\mathrm{T}$ & & & & 0.459 & 0.443 & 0.579 & 0.433 & 0.437 & 0.908 & 0.483 & 0.450 & 0.461 \\
\hline H11 & $\mathrm{C}$ & & $\mathrm{T}$ & & & & 0.293 & 0.265 & 0.304 & 0.295 & 0.247 & 0.197 & 0.291 & 0.287 & 0.902 \\
\hline \multirow[t]{2}{*}{ H12 } & $\mathrm{T}$ & & $\mathrm{C}$ & & & & 0.248 & 0.292 & 0.094 & 0.272 & 0.317 & 0.279 & 0.226 & 0.264 & 0.251 \\
\hline & & & & $0.031^{*}$ & 0.067 & 0.400 & & & & & & & & & \\
\hline H13 & & G & $\mathrm{T}$ & & & & 0.468 & 0.389 & $0.009 *$ & 0.459 & 0.360 & $0.021 *$ & 0.477 & 0.423 & 0.181 \\
\hline H14 & & A & $\mathrm{T}$ & & & & 0.281 & 0.317 & 0.210 & 0.269 & 0.320 & 0.180 & 0.292 & 0.314 & 0.511 \\
\hline H15 & & G & $\mathrm{C}$ & & & & 0.251 & 0.294 & 0.101 & 0.272 & 0.320 & 0.238 & 0.232 & 0.264 & 0.348 \\
\hline
\end{tabular}

CAD, coronary artery disease; SNP, single-nucleotide polymorphism. Haplotype with frequencies $>0.01$ were estimated using SNPAlyze software. $P$ value was calculated by permutation test using the bootstrap method. $* P<0.05$.

Table 5: Odds ratios and 95\% confidence intervals (CI) for each confounding factor and haplotype associated with CAD

\begin{tabular}{lccc}
\hline Risk factors & Odd ratios & $\mathbf{9 5 \%} \mathbf{C I}$ & $\boldsymbol{P}$ value \\
\hline H13 haplotype (homozygote) & 1.887 & $1.188-2.995$ & $0.007^{*}$ \\
DM & 2.606 & $1.731-3.922$ & $<0.001^{*}$ \\
Hypertension & 1.093 & $0.758-1.576$ & 0.634 \\
LDL & 1.385 & $1.013-1.894$ & $0.041^{*}$ \\
TC & 1.542 & $1.134-2.077$ & $0.026^{*}$ \\
TG & 1.121 & $0.980-1.283$ & 0.096 \\
Creatinine & 1.006 & $0.997-1.016$ & 0.178 \\
\hline
\end{tabular}

CAD, coronary artery disease; DM, diabetes mellitus; LDL, low-density lipoprotein; TC, total cholesterol; TG, triglycerides; $* P<0.05$.

cardiovascular or metabolic or endocrine diseases, for example, they may have hypertension, diabetes mellitus (DM), and lipids disorders, which meant that the subjects in control group may share the same risk factors as subjects in CAD group except for that the results of coronary angiography were normal. It could decrease the effects of environmental factors of CAD, increase the homogeneity of the two groups and focus mainly on the effects of genetic factors.

There are some limitations in the present study. In Chinese women of this study, the G-T haplotype frequency constructed by SNP2-SNP5 was higher in CAD patients 
when compared with controls, but the $P$ value did not reach significance $(P=0.181)$. We believed the enlargement in women samples may lead to more significant difference.

At last, the association between the human GOSR2 gene and CAD has been addressed for the first time in the Chinese Han population. The data indicates that in Chinese Han population, the G-T haplotype established by rs3785889-rs16941382 of the human GOSR2 gene might be the risk marker for coronary artery disease.

\section{MATERIALS AND METHODS}

\section{Ethics statement}

Written informed consent was obtained from all participants. All participants explicitly provided permission for DNA analyses as well as collection of relevant clinical data. This study was approved by the Ethics Committee of People's Hospital of Shaanxi Province. It was conducted according to the standards of the Declaration of Helsinki. Authors have access to information that could identify individual participants during or after data collection.

\section{Subjects}

The subjects were from the Han population who lived in Shaanxi. All patients and controls had a differential diagnosis for chest pain encountered in the Cardiac Catheterization Department of People's Hospital of Shaanxi Province from January in 2015 to December in 2016. The procedures of coronary angiography were undertaken by highly skilled physicians using the Judkins approach. The findings of coronary angiography were interpreted by at least two experienced imaging specialists and the final diagnosis of CAD was made according to the angiography report.

We randomly recruited 283 Han patients with CAD and 280 age matched controls. The CAD was defined as the presence of at least one significant coronary artery stenosis of more than $50 \%$ luminal diameter in coronary angiography. All control subjects also underwent the coronary angiography and had no coronary artery stenosis and did not show clinical or electrocardiogram evidence of myocardial infarction or CAD. Control subjects were not healthy individuals, some of them had hypertension, some of them had diabetes mellitus (DM), and some of them had lipids disorders, which meant that the subjects in control group were exposed to the same risk factors as subjects in CAD group except that the results of coronary angiography were normal.

The data of traditional coronary risk factors, including blood lipids, hypertension and DM were collected from all study participants. The diagnosis of hypertension was established if patients were on antihypertensive medication or if the mean of 3 measurements of systolic blood pressure (SBP) $\geq 140$ $\mathrm{mm} \mathrm{Hg}$ or diastolic blood pressure (DBP) $\geq 90 \mathrm{~mm}$ $\mathrm{Hg}$, respectively. Diabetes mellitus was defined on the basis of the World Health Organization (WHO) criteria. In addition, individuals with fasting plasma glucose $\geq 7.0 \mathrm{mmol} / \mathrm{L}$ or with a history of diabetes or treatment with insulin were considered diabetic. All patients with impaired renal function, malignancy, connective tissue disease, valvular disease or chronic inflammatory disease were excluded.

\section{SNP selection}

GOSR2 gene in human has three transcript variants to encode three different isoforms (isoform $\mathrm{A}$, isoform $\mathrm{B}$, isoform C). The isoform A of GOSR2 gene has the longest length among the three isoforms, it consists of 212 amino acids and is located on chromosome 17q21. This gene is approximately 18.25 kilobase pairs $(\mathrm{kbp})$ and contains six exons separated by five introns.

In this study, we screened the data on the International HapMap Project website (http://hapmap.ncbi. nlm.nih.gov/index.html.en) for the Tag SNPs of GOSR2 gene. SNPs with relatively high minor allele frequencies (MAF) have been shown to be useful as genetic markers in genetic association studies, so we selected three SNPs (rs3785889, rs197932, and rs16941382) which had a MAF of $>0.1$ as the tag SNPs in Chinese population. rs 197932 is located $26 \mathrm{kbp}$ upstream from the start codon in exon 1 , while rs 16941382 is located $25 \mathrm{kbp}$ downstream from the stop codon in exon six. Meanwhile, we also include rs17608766 and rs197922 which may be associated with blood pressure and coronary heart disease respectively in GOSR2 gene [8, 21].

We designated the five SNPs as SNP1 (rs197932, C_2592633_10), SNP2 (rs3785889, C_2960489_10), SNP3 (rs197922, C_2275273_10), SNP4 (rs17608766, C_33589426_10), and SNP5 (rs16941382, C_33589395_10), which were in order of increasing distance from the $5^{\prime}$ end of the gene.

\section{Genotyping}

Venous blood samples were collected from all participants in fasting state, and genomic DNA was extracted from the peripheral blood leukocytes using phenol and chloroform extraction method in Central Laboratory of People's Hospital of Shaanxi Province from January in 2015 to December in 2016 and stored in $-80^{\circ} \mathrm{C}$ refrigerator for further genotyping [22, 23].

The DNA samples were carried on dry ice to Laboratory Department of Shanghai GENESKY Biological Technology Co., Ltd. (http://www.geneskies. com/) via airplane for genotyping in January in 2017. Genotyping was performed using the TaqMan SNP Genotyping Assay (Applied Biosystems). The primers 
and probes used in the TaqMan SNP Genotyping Assays (Applied Biosystems) were chosen based on information available at the ABI website (http://www. appliedbiosystems.com/AB_Home/index.htm).

Polymerase chain reaction (PCR) amplification was performed using $2.5 \mu \mathrm{l}$ of TaqMan Universal Master Mix, No AmpErase UNG (2×) (Applied Biosystems) in a 5 $\mu \mathrm{l}$ final reaction volume, along with $2 \mathrm{ng}$ DNA, $2.375 \mu \mathrm{l}$ ultrapure water, $0.079 \mu \mathrm{l}$ Tris-EDTA (TE) buffer $(1 \times), 0.046$ $\mu \mathrm{l}$ TaqMan SNP Genotyping Assay Mix (40×) containing a $331.2 \mathrm{nmol} / \mathrm{l}$ final concentration of primers and a 73.6 $\mathrm{nmol} / \mathrm{l}$ final concentration of the probes. The thermal cycling conditions were as follows: $50^{\circ} \mathrm{C}$ for $2 \mathrm{~min} ; 95^{\circ} \mathrm{C}$ for 10 min; 50 cycles of $95^{\circ} \mathrm{C}$ for $15 \mathrm{~s}$; and $60^{\circ} \mathrm{C}$ for $1 \min [24$, $25]$. The plates were read on the sequence detection system 7900 instrument with the end-point analysis mode of the sequence detection system version 1.6.3 software package (Applied Biosystems). The genotypes were determined visually based on the dyecomponent fluorescent emission data depicted in the X-Y scatter-plot of the sequence detection system software. The genotypes results were saved in two separate output files for later comparison [26].

\section{Statistical analysis}

All continuous variables were expressed as mean \pm S.D. Differences in continuous variables between the $\mathrm{CAD}$ patients and control subjects were analyzed using the Mann-Whitney $U$-test. Differences in categorical variables were analyzed using Fisher's exact test. Differences in distributions of genotypes and alleles between CAD patients and control subjects were analyzed using Fisher's exact test. Based on the genotype data of the genetic variations, we performed linkage disequilibrium and haplotype-based case-control analyses using the software SNPAlyze version 8.2 (Dynacom, Yokohama, Japan) [27]. The pairwise linkage disequilibrium analysis was performed using four SNP pairs. We used | D'| values of $>0.5$ to assign SNP locations to one haplotype block. SNPs with an $r^{2}$ value $>0.5$ were selected as tagged. In the haplotype-based case-control analysis, haplotypes with a frequency of $<0.01$ were excluded. Logistic regression analysis was performed to assess the contribution of the major risk factors after constructing diplotypes for each subject by SNPAlyze version 8.2 (Dynacom, Yokohama, Japan). Statistical significance was established at $P<0.05$. Statistical analyses were performed using SPSS software for Windows, version 17.0 (SPSS, Chicago, IL).

\section{CONFLICTS OF INTEREST}

We state that we have no conflicts to disclose.

\section{FUNDING}

This paper was funded by National Natural Science Funds of China (Grant No. 81500308) and Social
Development Breakthrough Project of Science and Technology Research and Development Plan of Shaanxi (Grant No. 2012K15-02-08).

\section{REFERENCES}

1. Frazier L, Johnson RL, Sparks E. Genomics and cardiovascular disease. Nurs Scholarsh. 2005;37:315-321.

2. Winkelmann BR, Hager J. Genetic variation in coronary heart disease and myocardial infarction: methodological overview and clinical evidence. Pharmacogenomics. 2000;1:73-94.

3. Nordlie MA, Wold LE, Kloner RA. Genetic contributors toward increased risk for ischemic heart disease. Mol Cell Cardiol. 2005;39:667-679.

4. Lowe SL, Peter F, Subramaniam VN, Wong SH, Hong W. A SNARE involved in protein transport through the Golgi apparatus. Nature. 1997;389:881-884.

5. Söllner T, Bennett MK, Whiteheart SW, Scheller RH, Rothman JE. A protein assembly-disassembly pathway in vitro that may correspond to sequential steps of synaptic vesicle docking, activation, and fusion. Cell. 1993;75:409-418.

6. Söllner T, Whiteheart SW, Brunner M, ErdjumentBromage H, Geromanos S, Tempst P, Rothman JE. SNAP receptors implicated in vesicle targeting and fusion. Nature. 1993;362:318-324.

7. Das S, Majhi PD, Al-Mugotir MH, Rachagani S, Sorgen P, Batra SK. Membrane proximal ectodomain cleavage of MUC16 occurs in the acidifying Golgi/post-Golgi compartments. Sci Rep. 2015;5:9759.

8. Meyer TE, Shiffman D, Morrison AC, Rowland CM, Louie JZ, Bare LA, Ross DA, Arellano AR, Chasman DI, Ridker PM, Pankow JS, Coresh J, Malloy MJ. GOSR2 Lys67Arg is associated with hypertension in whites. Am J Hypertens. 2009;22:163-168.

9. Pan S, Nakayama T, Sato N, Izumi Y, Soma M, Aoi N, Ma Y, Hinohara S, Doba N. A haplotype of the GOSR2 gene is associated with myocardial infarction in Japanese men. Genet Test Mol Biomarkers. 2012;17:481-488.

10. Rothman JE. Mechanisms of intracellular protein transport. Nature. 1994;372:55-63.

11. Hay JC, Scheller RH. SNAREs and NSF in targeted membrane fusion. Curr Opin Cell Biol. 1997;9:505-512.

12. Ernst JA, Brunger AT. High resolution structure, stability, and synaptotagmin binding of a truncated neuronal SNARE complex. J Biol Chem. 2003;278:8630-8636.

13. Poirier MA, Xiao W, Macosko JC, Chan C, Shin YK, Bennett MK. The synaptic SNARE complex is a parallel four-stranded helical bundle. Nat Struct Biol. 1998;5:765-769.

14. Pan S, Nakayama T, Sato N, Izumi Y, Soma M, Aoi N, Ma Y. A haplotype of the GOSR2 gene is associated with 
essential hypertension in Japanese men. Clin Biochem. 2013;46:760-765.

15. Morris RW, Kaplan NL. On the advantage of haplotype analysis in the presence of multiple disease susceptibility alleles. Genet Epidemiol. 2002;23:221-233.

16. Simino J, Shi G, Bis JC, Chasman DI, Ehret GB, Gu X, Guo X, Hwang SJ, Sijbrands E, Smith AV, Verwoert GC, Bragg-Gresham JL, Cadby G. Gene-age interactions in blood pressure regulation: a large-scale investigation with the CHARGE, Global BPgen, and ICBP Consortia. Am J Hum Genet. 2014;95:24-38.

17. Ghanbari M, de Vries PS, de Looper H, Peters MJ, Schurmann C, Yaghootkar H, Dörr M, Frayling TM, Uitterlinden AG, Hofman A, van Meurs JB, Erkeland SJ, Franco OH, Dehghan A. A genetic variant in the seed region of miR-4513 shows pleiotropic effects on lipid and glucose homeostasis, blood pressure, and coronary artery disease. Hum Mutat. 2014;35:1524-1531.

18. Hay JC, Klumperman J, Oorschot V, Steegmaier M, Kuo CS, Scheller RH. Localization, dynamics, and protein interactions reveal distinct roles for ER and golgi SNAREs. J Cell Biol. 1998;141:1489-1502.

19. Söllner T, Bennett MK, Whiteheart SW, Scheller RH, Rothman JE. A protein assembly-disassembly pathway in vitro that may correspond to sequential steps of synaptic vesicle docking, activation, and fusion. Cell. 1993;75:409-418.

20. Koliwer J, Park M, Bauch C, von Zastrow M, Kreienkamp HJ. The golgi-associated PDZ domain protein PIST/ GOPC stabilizes the $\beta 1$-adrenergic receptor in intracellular compartments after internalization. J Biol Chem. 2015;290:6120-6129.

21. Ehret GB, Munroe PB, Rice KM, Bochud M, Johnson AD, Chasman DI, Smith AV, Tobin MD, Verwoert GC, Hwang
SJ, Pihur V, Vollenweider P, O'Reilly PF, et al. Genetic variants in novel pathways influence blood pressure and cardiovascular disease risk. Nature. 2011;478:103-109.

22. Pan S, Liu ZW, Lv Y, Song WQ, Ma X, Guan GC, Zhang Y, Zhu SM, Liu FQ, Liu B, Tang ZG, Wang JK. Association between neutrophilic granulocyte percentage and depression in hospitalized patients with heart failure. BMC Psychiatry. 2016;16:446.

23. Zhao N, Mi L, Liu X, Pan S, Xu J, Xia D, Liu Z, Zhang Y, Xiang Y, Yuan Z, Guan G, Wang J. Combined value of red blood cell distribution width and global registry of acute coronary events risk score for predicting cardiovascular events in patients with acute coronary syndrome undergoing percutaneous coronary intervention. PLoS One. 2015; 10:e0140532.

24. Li G, Sun X, Zhao D, He L, Zheng L, Xue J, Wang B, Pan H. A promoter polymorphism in APJ gene is significantly associated with blood pressure changes and hypertension risk in Chinese women. Oncotarget. 2016;7:86257-86265. https://doi.org/10.18632/oncotarget.13370.

25. Zheng YY, Xie X, Ma YT, Fu ZY, Ma X, Yang YN, Li XM, Pan S, Adi D, Chen BD, Liu F. Association of C5L2 genetic polymorphisms with coronary artery disease in a Han population in Xinjiang, China. Oncotarget. 2017;8:85908596. https://doi.org/10.18632/oncotarget.14353.

26. Livak KJ, Marmaro J, Todd JA. Towards fully automated genome-wide polymorphism screening. Nat Genet. 1995;9:341-342.

27. Maiolino G, Lenzini L, Pedon L, Cesari M, Seccia TM, Frigo AC, Rossitto G, Caroccia B, Rossi GP. Lipoprotein-associated phospholipase A2 single-nucleotide polymorphisms and cardiovascularevents in patients with coronary artery disease. J Cardiovasc Med. 2015;16:29-36. 